\title{
Molecular Docking Studies; 1,3 Thiazines Derivatives
}

\author{
Khan Sana ${ }^{1 *}$, Singh Gurdeep ${ }^{1}$ andSainy Jitendra ${ }^{2}$ \\ ${ }^{1}$ Department of Pharmaceutical Chemistry, Oriental College of Pharmacy and \\ Research, Indore, MP, India \\ ${ }^{2}$ School of Pharmacy, Devi Ahilya University, Indore, MP, India \\ *Corresponding Author: Khan Sana, Department of Pharmaceutical Chemistry, \\ Oriental College of Pharmacy and Research, Indore, MP, India.
}

Received: June 15, 2020

Published: June 26, 2020

(C) All rights are reserved by Khan Sana., et al.

\begin{abstract}
Some novel derivatives of 1,3-thiazine have been synthesized by the condensation of 2-hydroxy-3-nitro5-chlorochalcones with thiourea and phenylthiourea in ethanol containing aqueous $\mathrm{KOH}$ solution. The synthesized ten 1,3 thiazine derivatives were subjected to molecular docking studies against E.coli Glucosamine-6 P Synthase in Complex with Fructose-6 P (PDB ID-4 AMV) and Crystal structure of Peptide deformylase from Staphylococcus aureus Complex with Actinonin (PDB ID-1Q1Y) usingMolegro Virtual Docker software. All synthesized compound have been screened for in-vitro evaluation of antimicrobial activities by agar plate techniques. The results indicated that all the synthesized 1,3 thiazine derivatives shows considerable antimicrobial activities on gram negative (E. coli) bacteria This study suggested that 1,3-thiazine derivatives possess more antimicrobial activities on gram negative (E. coli) bacteria than gram positive bacteria (S.aureus).

Keywords: 1, 3 Thiazine; Molecular Docking; Antimicrobial Activities; Thiourea; Phenyl Thiourea
\end{abstract}

\section{Introduction}

The heterocyclic compounds which contain nitrogen, sulphur and oxygen possess a huge significance within the field of medicinal chemistry. Thiazines are very useful units within the fields of medicinal and pharmaceutical chemistry and are reported to exhibit a spread of biological activities [1]. A large number of thiazine derivatives also exhibited various biological activities such as antimicrobial [2], anti-inflammatory [3], antioxidant, antipyretic, antitumor [4], calcium channel modulators [5]. 1, 3-thiazine derivatives and their evaluation as potential antimicrobial agents [6]. Literature review reveals that chalcones exhibited various biological and pharmacological activities such as antimicrobial [7], antifungal [8], analgesic [9], anti-platelet [10], insecticidal [8], anti-malarial [11], antiviral [7] activities. The reaction of thiourea and phenyl thiourea with $\alpha, \beta$-unsaturated ketones results in 1, 3 thiazine derivatives [12]. Different chalcone derivatives are used as the starting material for the synthesis of 1, 3 thiazine derivatives. Based on the careful analysis of literature survey, the well focused and biologically potent 1, 3 thiazines derivatives were synthesized via three stages of reaction.

In the present work involves the synthesis of chalcones by using aryl aldehyde and 2-Hydroxy-3-nitro-5-chloroacetophenone. Then the chalcones are treated with thiourea and phenyl thiourea to give 1, 3 thiazine derivatives. Molecular docking studies against E.coli Glucosamine-6 P Synthase in Complex with Fructose-6 P (PDB ID-4 $\mathrm{AMV}$ ) and crystal structure of peptide deformylase from Staphylococcus aureus complex with actinonin (PDB ID-1Q1Y) were done to compare the antimicrobial activities of synthesized 1, 3-thiazine derivatives.

\section{Materials and Methods}

All the solvents and chemical reagents were collected from P.C Chem. pharmaceutical. The melting points of the organic compounds were determined by open capillary tube method and are uncorrected. The solubility of the synthesized compounds was tested in various solvents like water, ethanol, chloroform, benzene, hexane etc.

\section{General procedure}

Preparation of 2-hydroxy-3-nitro-5-chloroacetophenone (2a)

2-Hydroxy-5-chloroacetophenone (3g) was dissolved in glacial acetic acid $(3 \mathrm{ml})$. Nitric acid was added drop wise with constant stirring to this reaction mixture. The temperature of the reaction mixture was maintained below $0^{\circ} \mathrm{C}$. The mixture was allowed to 
stand for 1 hour. It was poured into ice cold water with stirring. A yellow solid then obtained was filtered, dried and crystallized from ethanol.

Preparation of 2-hydroxy-3-nitro- 5-chlorochalcones (3a-e)

2-Hydroxy-3-nitro-5-chloroacetophenone (2a), (0.1M) was dissolved in ethanol $(50 \mathrm{ml})$ and derivatives of benzaldehyde $(0.1 \mathrm{M})$ were added to the above solution and the mixture was heated to boiling. Aq. sodium hydroxide solution $(40 \%, 40 \mathrm{ml})$ was added drop wise with constant stirring. The mixture was stirred mechanically at room temperature for about half an hour and kept overnight. It was then acidified by hydrochloric acid solution (50\%). The solid separated was filtered and washed with sodium bicarbonate $(10 \%)$ followed by water. The crude product was crystallized from ethanol acetic acid mixture (3a-e).

Preparation of 4-(2-hydroxy-3-nitro-5-chlorophenyl)-6(aryl)-2-imino- 3,6 dihydro-1, 3-thiazines (4a-e)

2-Hydroxy-3-nitro-5-chlorochalcone (3a-e), (0.01M) and thiourea $(0.01 \mathrm{M})$ were dissolved in ethanol $(25 \mathrm{ml})$.To this aq. $\mathrm{KOH}$ solution $(0.02 \mathrm{M})$ was added (prepared from $\mathrm{KOH}$ in small amount of distilled water). The reaction mixture was refluxed for 2.5 hours, cooled, diluted with water and acidified with 1:1 $\mathrm{HCl}$. The product was filtered, dried and crystallized from ethanol (4a-e).

Preparation of 4-(2-hydroxy-3-nitro-5-chlorophenyl)-6-(aryl)2-iminophenyl- 3, 6 dihydro-1, 3-thiazine (5a-e)

2-hydroxy-3-nitro-5-chlorochalcone (4a-e), (0.01M) dissolved in ethanol $(25 \mathrm{ml})$ were added to phenylthiourea $(0.01 \mathrm{M})$.To this aq. $\mathrm{KOH}$ solution $(0.02 \mathrm{M})$ was added. The reaction mixture was refluxed for 2.5 hours, cooled, diluted with water and acidified with concentrate $\mathrm{HCl}$. The product was filtered, dried and crystallized from ethanol (5a-e). (Scheme: Synthesis of 1, 3 Tiazine derivatives)

\section{Characterization of the compounds}

The melting points of all synthesized compounds were determined in open capillary tubes and are uncorrected. The purity of final compounds was checked by TLC on silica gel G plate using hexane and ethyl acetate visualized in iodine chamber.

\begin{tabular}{|l|c|c|c|c|c|c|}
\hline Compound Code & $\mathbf{R}$ & Molecular formula & Molecular weight & M.P( ${ }^{\mathbf{O}} \mathbf{C}$ & \% yield & $\mathbf{R}_{\mathbf{f}}$ value \\
\hline $4 \mathrm{a}$ & $\mathrm{Cl}$ & $\mathrm{C}_{16} \mathrm{H}_{11} \mathrm{Cl}_{2} \mathrm{~N}_{3} \mathrm{O}_{3} \mathrm{~S}$ & 396.25 & 120 & 76 & 0.55 \\
\hline $4 \mathrm{~b}$ & $\mathrm{Br}$ & $\mathrm{C}_{16} \mathrm{H}_{11} \mathrm{BrClN}_{3} \mathrm{O}_{3} \mathrm{~S}$ & 440.70 & 145 & 68 & 0.58 \\
\hline $4 \mathrm{c}$ & $\mathrm{OCH}_{3}$ & $\mathrm{C}_{17} \mathrm{H}_{14} \mathrm{ClN}_{3} \mathrm{O}_{4} \mathrm{~S}$ & 391.83 & 102 & 58 & 0.68 \\
\hline $4 \mathrm{~d}$ & $\mathrm{NO}_{2}$ & $\mathrm{C}_{16} \mathrm{H}_{11} \mathrm{ClN}_{4} \mathrm{O}_{5}$ & 406.01 & 138 & 70 & 0.64 \\
\hline $4 \mathrm{e}$ & $\mathrm{OH}$ & $\mathrm{C}_{16} \mathrm{H}_{12} \mathrm{ClN}_{3} \mathrm{O}_{4} \mathrm{~S}$ & 377.02 & 132 & 51 & 0.72 \\
\hline $5 \mathrm{a}$ & $\mathrm{Cl}$ & $\mathrm{C}_{22} \mathrm{H}_{15} \mathrm{Cl}_{2} \mathrm{~N}_{3} \mathrm{O}_{3} \mathrm{~S}$ & 472.34 & 110 & 74 & 0.69 \\
\hline $5 \mathrm{~b}$ & $\mathrm{Br}$ & $\mathrm{C}_{22} \mathrm{H}_{15} \mathrm{BrClN}_{3} \mathrm{O}_{3} \mathrm{~S}$ & 516.79 & 157 & 75 & 0.49 \\
\hline $5 \mathrm{c}$ & $\mathrm{OCH}$ & $\mathrm{C}_{23} \mathrm{H}_{18} \mathrm{ClN}_{3} \mathrm{O}_{4} \mathrm{~S}$ & 467.92 & 142 & 54 & 0.51 \\
\hline $5 \mathrm{~d}$ & $\mathrm{NO}_{2}$ & $\mathrm{C}_{22} \mathrm{H}_{15} \mathrm{ClN}_{4} \mathrm{O}_{5} \mathrm{~S}$ & 482.90 & 138 & 60 & 0.35 \\
\hline $5 \mathrm{e}$ & $\mathrm{OH}$ & $\mathrm{C}_{22} \mathrm{H}_{16} \mathrm{ClN}_{3} \mathrm{O}_{4} \mathrm{~S}$ & 453.90 & 140 & 65 & 0.55 \\
\hline
\end{tabular}

Table 1: Physical data of synthesized 1,3 thiazine derivatives.

\section{Molecular docking studies}

Docking is employed to predict the binding orientation of small molecule drug candidates to their protein targets so as to successively predict the affinity and activity of the tiny molecule. The structure of the protein E.coli Glucosamine-6 P Synthase in Complex with Fructose-6 P (PDB ID-4 AMV) and Crystal structure of Peptide deformylase from Staphylococcus aureus Complex with Actinonin (PDB ID- 1Q1Y) was retrieved from the RCSB (research Collaboratory for structure bioinformatics) Protein Data Bank. The binding site of protein was defined by selecting all atoms within $10 \AA$, which was found by redocking the native ligand at the ac- tive site and docked using Molegro Virtual Docker. Molegro Virtual Docker is an excellent, non-commercial docking program that is widely used. Molegro Virtual Docker 6.0 developed by CLC drug discovery Workbench.

\section{Results and Discussion}

In the present work totally 10 compounds were synthesized in two scheme.Step 1 involves the formation of chalcones from 2-Hydroxy-3-nitro-5-chloroacetophenone.The step 1 product (chalcone) reacted with thiourea or phenyl thiourea in presence of potassium hydroxide undergo cyclization to form 1,3-thiazine derivatives. Molecular docking studies were carried out for the syn- 


\section{Scheme: Synthesis of 1, 3 Thiazine derivatives}<smiles>[R]c1ccc(C(C)=O)cc1</smiles>

1a<smiles>CC(=O)c1cc(Cl)cc([N+](=O)[O-])c1O</smiles>

2a

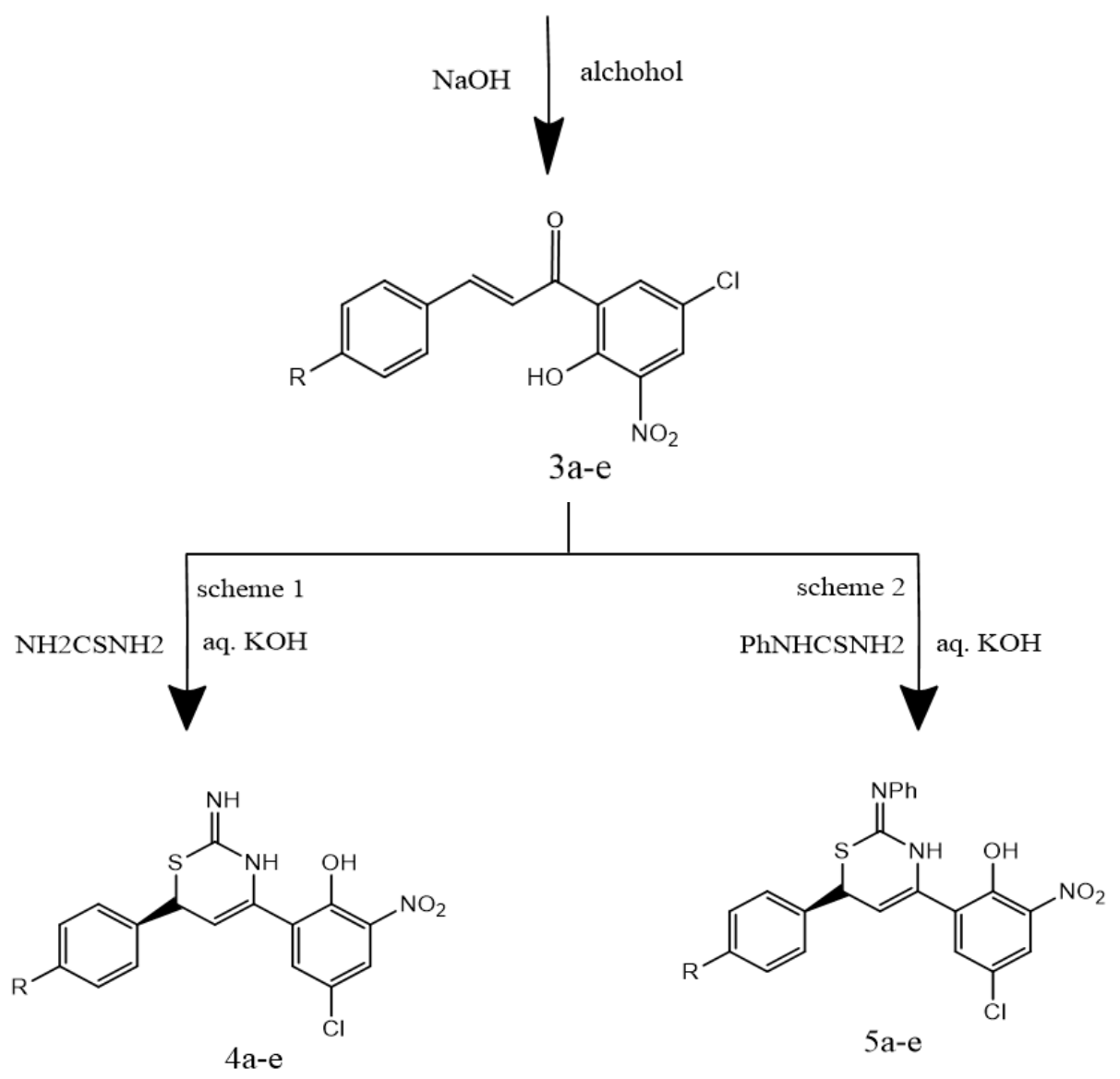

Where $\mathrm{R}=\mathrm{Cl}, \mathrm{Br}, \mathrm{OCH} 3, \mathrm{NO} 2, \mathrm{OH}$

Scheme: Synthesis of 1, 3 Tiazine derivatives 


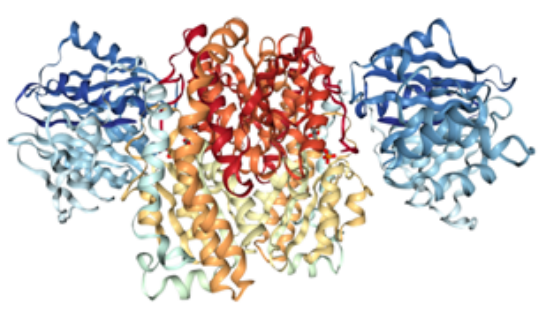

Figure 1: Structure of 4AMV (PDB ID).

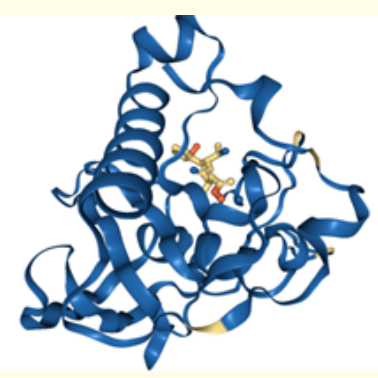

Figure 2: Structure of 1Q1Y (PDB ID).

thesized compounds against E.coli Glucosamine-6 P Synthase in Complex with Fructose-6 P (PDB ID-4 AMV) and Crystal structure of Peptide deformylase from Staphylococcus aureus Complex with Actinonin (PDB ID-1Q1Y) by using Molegro Virtual Docker software which gives an insight in to the binding modes for the various inhibitors. Out of 10 inhibitors analyzed 5a has showed Mol Dock Score of -110.723 for E.coli and $5 \mathrm{~d}$ has showed Mol Dock Score of -96.683 for S.aureus. Then all ten derivatives of 1, 3 thiazine were screened for their antimicrobial activity against gram positive bacteria viz. S. aureus and gram negative bacteria viz. E. coli species at

\begin{tabular}{|l|c|c|c|}
\hline Compound code & MolDock Score & Rerank Score & HBond \\
\hline $4 \mathrm{a}$ & -86.7749 & -67.5634 & -6.83585 \\
\hline $4 \mathrm{~b}$ & -88.8064 & -74.5592 & -6.18152 \\
\hline $4 \mathrm{c}$ & -93.706 & -76.7804 & -3.95941 \\
\hline $4 \mathrm{~d}$ & -86.8956 & -58.2635 & -9.75651 \\
\hline $4 \mathrm{e}$ & -106.654 & -81.0678 & -12.0967 \\
\hline $5 \mathrm{a}$ & -110.723 & -78.4613 & -5.48575 \\
\hline $5 \mathrm{~b}$ & -82.4321 & 19.6867 & -6.4191 \\
\hline $5 \mathrm{c}$ & -86.7144 & 19.3956 & -6.50447 \\
\hline $5 \mathrm{~d}$ & -88.6181 & 10.7845 & -6.41836 \\
\hline $5 \mathrm{e}$ & -81.9273 & 19.5981 & -6.47967 \\
\hline
\end{tabular}

Table 2: Summary of docking score of all synthesized 1,3-thiazine derivatives against the target E. coli Glucosamine-6 P Synthase in Complex with Fructose-6 P (PDB ID: 4 AMV).

\begin{tabular}{|l|c|c|c|}
\hline Compound code & Mol Dock Score & Rerank Score & HBond \\
\hline $4 \mathrm{a}$ & -83.9601 & -66.2623 & -4.97171 \\
\hline $4 \mathrm{~b}$ & -84.5862 & -66.6038 & -4.37323 \\
\hline $4 \mathrm{c}$ & -87.6422 & -70.5666 & -6.48139 \\
\hline $4 \mathrm{~d}$ & -85.0538 & -69.3519 & -4.87202 \\
\hline $4 \mathrm{e}$ & -83.252 & -66.2025 & -3.71184 \\
\hline $5 \mathrm{a}$ & -87.4778 & -66.6463 & -7.1557 \\
\hline $5 \mathrm{~b}$ & -92.1642 & -75.5591 & -4.89751 \\
\hline $5 \mathrm{c}$ & -95.4961 & -77.3788 & -3.69138 \\
\hline $5 \mathrm{~d}$ & -96.5073 & -80.1216 & -4.02885 \\
\hline $5 \mathrm{e}$ & -94.7954 & -78.3154 & -5.3336 \\
\hline
\end{tabular}

Table 3: Summary of docking score of all synthesized 1,3-thiazine derivatives against the target Crystal structure of Peptide deformylase from Staphylococcus Aureus Complex with Actinonin (PDB ID:1Q1Y).

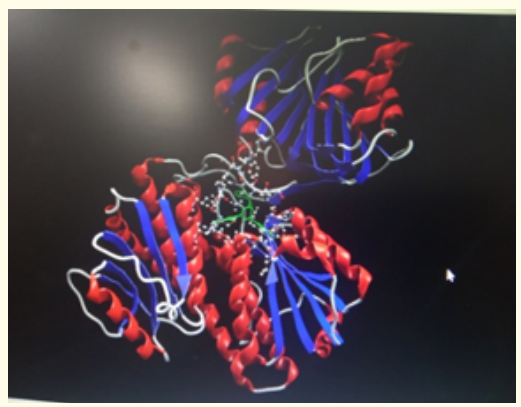

Figure 3: Docking complex of 5a with 4AMV.

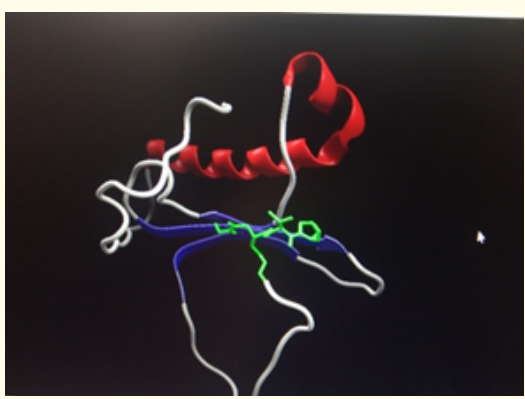

Figure 4: Docking complex of $1 \mathrm{Q} 1 \mathrm{Y}$ with $5 \mathrm{~d}$.

conc. of $1000 \mu \mathrm{m}$ azithromycin as a standard. DMF was used as a solvent control using agar plate techniques. The zone of inhibition formed were measured in $\mathrm{mm}$ and shown in table 4. 


\begin{tabular}{|c|c|c|}
\hline \multirow{2}{*}{$\begin{array}{c}\text { Compound } \\
\text { Code }\end{array}$} & \multicolumn{2}{|c|}{ Zone of inhibition (mm) } \\
\cline { 2 - 3 } & E. coli & S. aureus \\
\hline $4 \mathrm{a}$ & 17 & 16 \\
\hline $4 \mathrm{~b}$ & 20 & 17 \\
\hline $4 \mathrm{c}$ & 23 & 19 \\
\hline $4 \mathrm{~d}$ & 19 & 17 \\
\hline $4 \mathrm{e}$ & 25 & 15 \\
\hline $5 \mathrm{a}$ & 26 & 19 \\
\hline $5 \mathrm{~b}$ & 17 & 18 \\
\hline $5 \mathrm{c}$ & 19 & 19 \\
\hline $5 \mathrm{~d}$ & 20 & 21 \\
\hline $5 \mathrm{e}$ & 17 & 21 \\
\hline
\end{tabular}

Table 4: Antimicrobial activities of all synthesized 1,3 thiazine derivatives.

\section{Conclusion}

Ten different 1, 3 Thiazine derivatives were synthesized from chalcones and thiourea or phenyl thiourea. The synthesized compounds were checked for their antimicrobial activity by molecular docking studies against E.coli Glucosamine-6 P Synthase in Complex with Fructose-6 P (PDB ID-4 AMV) and Crystal structure of Peptide deformylase from Staphylococcus aureus Complex with Actinonin (PDB ID-1Q1Y) by using Molegro Virtual Docker software. Then in-vitro evaluation of antimicrobial activity of all synthesized 1, 3-Thiazine derivatives were performed and all having considerable antimicrobial activity. From the above results it would be concluded that 1, 3-thiazines derivatives possess more antimicrobialactivities on gram negative (E. coli) bacteria than gram positive bacteria (S.aureus).

\section{Bibliography}

1. Ram S Ganorkar., et al. "Synthesis, characterization and antibacterial activities of some new Bromo/ Nitro 1,3- Thiazines". Rasayan Jouranal of Chemistry 6.1 (2013): 65-67.

2. A Nagaraj and CS Reddy. "Synthesis and biological study of novel bis-chalcones, bis-thiazines and bis-pyrimidines". Journal of the Iranian Chemical Society 5.2 (2008): 262-267.

3. R Kalirajan., et al. "Synthesis and biological evaluation of some heterocyclic derivatives of chalcones". International Journal of ChemTech Research 1.1 (2009): 27-34.

4. Sayaji S Didwagh and Pravina B Piste. "Synthesis and antimicrobial activity of thiazine derivatives". Journal of Chemical and Pharmaceutical Research 5.4 (2013): 171-174.
5. R Sridhar and PT Perumal. "A new protocol to synthesize 1,4-dihydropyridines by using 3,4,5- trifluorobenzeneboronic acid as a catalyst in ionic liquid: synthesis of novel 4-(3-carboxyl-1H-pyrazol-4-yl)-1,4-dihydropyridines". Tetrahedron 61 (2005): 2465-2470.

6. M Koketsu K Tanaka., et al. "Synthesis of 1,3-thiazine derivatives and their evaluation as potential antimycobacterial agents". European Journal of Pharmaceutical Sciences 15.3 (2002): 307-331.

7. Y Rajendra Prasad., et al. "Synthesis and Antimicrobial Activity of Some Chalcone Derivatives". E-Journal of Chemistry 5 (2008): 461-466.

8. AK Parikh and KK Desai. "Synthesis and Antibacterial Activity of Chalcones and Pyrimidine-2-ones, 2". (2005): 109-112.

9. GS Viana., et al. "Analgesic and Antiinflammatory Effects of Chalcones Isolated From Myracrodruon Urundeuva allemão". Journal of Phytomedicine 10 (2003): 189.

10. LM Zhao., et al. "Synthesis and Evaluation of Antiplatelet Activity of Trihydroxychalcone Derivatives". Medicinal Chemistry Letters 15 (2005): 5027.

11. M Liu., et al. "Antimalarial Alkoxylated and Hydroxylated Chalcones [Corrected]: Structure-Activity Relationship Analysis". Journal of Medicinal Chemistry 44 (2001): 4443.

12. SP Rathod., et al. "Synthesis and antibacterial activities of chloro- substituted-1,3- Thiazines Rasayan". Jouranal of Chemistry 3.2 (2010): 363-367.

\section{Assets from publication with us}

- Prompt Acknowledgement after receiving the article

- Thorough Double blinded peer review

- Rapid Publication

- Issue of Publication Certificate

- High visibility of your Published work Website: $\underline{w w w . a c t a s c i e n t i f i c . c o m / ~}$

Submit Article: www.actascientific.com/submission.php Email us: editor@actascientific.com Contact us: +919182824667 